ISSN- 2394-5125

VOL 7, ISSUE 19, 2020

\title{
STRUCTURE OF THE RHETORIC IN KABAR SIANG AND BREAKING NEWS PROGRAMS ON TVONE
}

\author{
Noermanzah $^{1}$, Dedi Setiawan ${ }^{2}$, Syaiful Abid ${ }^{3}$, Reni Kusmiarti ${ }^{4}$, Agus Rofi $^{3} i^{5}$ \\ ${ }^{1}$ Bengkulu University, Bengkulu City, Indonesia, \\ ${ }^{2}$ STKIP PGRI Lubuklinggau, Lubuklinggau City, Indonesia, \\ ${ }^{3}$ STKIP PGRI Lubuklinggau, Lubuklinggau City, Indonesia, \\ ${ }^{4}$ Universitas Muhammadiyah Bengkulu, Bengkulu City, Indonesia ${ }^{5}$ Universitas Majalengka, Majalengka City, \\ Indonesia \\ E-mail: noermanzah@unib.ac.id, dedy4410@yahoo.com, syaiful2012abid@yahoo.co.id, , \\ renikusmiarti@umb.ac.id,, agusrafii@unma.ac.id
}

Received: 14 April 2020 Revised and Accepted: 8 August 2020

\begin{abstract}
Special news programs are very popular with the community if they have a good news structure. For this reason, the objective of this research was to describe the structure of news at the Kabar Siang and Breaking News programs on TvOne. The research method uses the content analysis method. Data collection techniques with record techniques and note taking techniques. Data analysis techniques with the following steps: setting questions, determining the definition of categories, step by step the formulation of categories, checking reliability, interpretation, and conclusions. Test the validity of data by discussing with experts, member check, and documenting all research data. The results showed that the news structure of the Kabar Siang and Breaking News program on TvOne began with an opening remarks, the Kabar Siang content section consisted of topics 1 to 42 from 8 segments, whereas Breaking News only had 1 topic from 1 segment, the final part was a closing marker and closing greetings. Each topic has a varied news structure consisting of leads, body of news, and news ending and contains 5W $1 \mathrm{H}$ elements. The structure of the Kabar Siang program is arranged in an inverted pyramid pattern in which the composition of news items starts from the most interesting, interesting, to less interesting based on the actuality and attractiveness of the news. While the structure of the Breaking News program only follows the pattern of the news structure namely leads, body of news, and news ending.
\end{abstract}

KEYWORDS: news structure, Kabar Siang news, Breaking News

\section{INTRODUCTION}

Print and online mass media are the main tools in the revolution era 4.0 that communicate the latest news with a range without being limited by space and time and function to provide the latest information needed by the public about various problems of life (Saragih, 2019). The more information obtained, it can also broaden a view and insight in the life around. By getting the right information, the public will be able to make the right decisions, both for themselves and for society in general for the sake of the nation's progress.

Barus (2010) explains that news is a report about everything about events or events in the form of facts that attract the attention of the public and are important to convey or publish so that they are known and become a general awareness for readers and listeners. While Chaer (2010), revealed that news is an event that is repeated in the form of words that are broadcast in writing in the written media (newspapers and magazines), or in the sound media (radio), or in the sound media accompanied by pictures (television). In addition, Kusumaningrat \& Kusumaningrat (2014) explained that news is actual information about an event or real events in the form of facts and opinions that attract people's attention.

Based on the opinion above, humans in everyday life really need some information as capital in building communication skills in society (Kusmiarti et al., 2020). Talking about information needs, it is important in people's lives to obtain information for the betterment of a community. Information is obtained through mass media reports, be it about politics, economics, crime, sports, and so on. This is very helpful in expanding an outlook and insight. This information trains people in literacy culture so as to produce a generation that has competence in digital literacy that is critical, innovative, and able to develop ideas in creating new businesses (Karto et al., 2019). Considering the important role of news in the community, in the writing and delivery of news certainly has elements of the news and signs that must be obeyed. This is made clear by Chaer (2010) which reveals that news elements include, what, who, why, where, when, and how or which is abbreviated as $5 \mathrm{~W}+1 \mathrm{H}$. While the structure in writing news includes, news headlines, news terraces (leads, intros), body of news (details), and the closing section (Badjuri, 2010; Harahap, 2018).

The role of news is also important in learning Indonesian in the 2013 curriculum with the Basic Competition writing news texts 3.1, 4.1 and 3.2, 4.2 in class VIII Middle School (Ministry of Education and Culture, 2017). 


\section{JOURNAL OF CRITICAL REVIEWS}

ISSN- 2394-5125

VOL 7, ISSUE 19, 2020

Writing news texts is one of four aspects of language skills, namely writing skills. Through mastering these skills, students are expected to be able to express ideas, thoughts, and feelings in written form. The writing in question must also have an impact on the ability to cultivate the politeness of students' language in the form of cooperation maxim (Syafryadin, 2020).

Based on the 2013 Indonesian subject curriculum above, the material for writing news texts is found in Basic Competencies 3.1, 4.1 and 3.2, 4.2. Basic Competencies 3.1, 4.1 with the subject matter one of which discusses news elements including, what, who, why, where, when, and how abbreviated to $5 \mathrm{~W}+1 \mathrm{H}$. Whereas in basic competence 3.2, 4.2 with the subject matter one of them discusses the structure of news texts including, headlines (led), body of news, and, tail of the news (Ministry of Education and Culture, 2017).

In addition, in learning to write news text students are also required to hone the ability to speak by reading the news text written. In speaking to convince other people or other groups, it is known as the art of speaking. Rhetoric is known as an art in speaking or speaking (Noermanzah, 2018). Simply put, rhetoric is a science that studies or questions about how to talk or talk in communication that has its own charm and charm, so that the listener or audiance can understand and be moved by his feelings. As in delivering news in public, it is demanded to have rhetorical abilities in speaking, such as the ability to process language with a strategy of ethos, pathos, and logos (Dewi, 2016; Noermanzah et al., 2019).

From the description above, the role of news is very important and useful both in the world of education in particular, and in the life of society in general. In the world of education there is learning about writing news and even reading news. While in the community the role of news is also very important in conveying information about events or events in the surrounding life. Therefore, the author is interested in conducting research on the news by studying the structure of news which includes, leads, content, and closing (news ending) and contains news elements including, what, who, why, where, when, and how abbreviated with $5 \mathrm{~W}+$ $1 \mathrm{H}$.

In modern times like today, electronic media has become an important part of people's lives to obtain information, one of them through television. Private television stations in Indonesia initially started with RCTI television stations, followed by SCTV, Indosiar, ANTV, and MNCTV. Following Metro TV, Trans TV, TvOne, Trans 7, Global TV, and NET TV are present starting in 2014. All of these television stations have news programs, be it news about disaster, politics, economics, crime, sports, social, religion , and so on (Surip, 2016). Of the several television stations above, TvOne is one of the most dominant television stations in presenting news programs. TvOne is a newcomer television station in the world of News. However, TvOne presents news forms with a new format that is different and unprecedented. News programs that are packaged are more interesting in the form of light discussions with the hottest topics with speakers and the public being broadcast live (Anwari, 2013).

TvOne has several excellent programs with different formats according to its slogan, "It's Different". The main programs of TvOne in 2018 are Damai Indonesiaku, Kabar Arena, Kabar Pagi, Apa Kabar Indonesia Pagi, Kabar Siang, Kabar Pasar, Kabar Petang, One Pride MMA, Menyingkap Tabir, Indonesia Lawyer Club (ILC), and Breaking News on impressions certain. Judging from its schedule in one 24-hour week, TvOne is one of the television stations that prioritizes news programs that air every day (TvOne, 2018).

TvOne has a series of achievements on programs presented in 2012 to 2017 from various categories (VIVA, 2018). TvOne is one of the television stations that almost every year gets awards from various categories, both categories of news programs, talk shows, sports, and other programs. News programs are now a special identity for television stations. Therefore, if a television station is without a news program, it will be a television station without an identity (Seto \& Morissan, 2013). One of the leading news programs on TvOne based on the News category as a special identity is Kabar Siang and Breaking News.

The Kabar Siang news program is one of the leading programs presented by TvOne by prioritizing the latest news. Likewise, Breaking News shows news events or events that were happening that day and were broadcast live reported live at the scene (TvOne, 2018). Therefore, the author is interested in conducting research in the news field at the Kabar Siang and Breaking News on TvOne in general covering the opening, content, and closing. Then specifically in the content section includes the news structure namely leads, body of news, and (closing) news ending, and contains news elements $(5 \mathrm{~W}+1 \mathrm{H})$.

Research about the news on programs on TvOne has been done a lot, one of which was done by Verawati, et al. (2014) with the title "Characteristics of Running Text Language in Morning News on the TvOne Channel". Research conducted by Verawati, et al. (2014) ie focus on diction and sentence patterns. The results showed that there were four types of diction and five types of sentence patterns found in running text, and found the most productive sentence patterns used were single sentences.

In addition, research was also carried out by Gusdian (2016) with the title "The Use of Greeting Words by Apa Kabar Indonesia (AKI) on TvOne". The study was conducted with a focus on the most dominant types of greeting words used and the frequency of their use. The results of his study contained eleven types of greeting words and the frequency of use of greetings in the form of the most dominant kinship title used in the utterance of the Apa Kabar Indonesia (AKI) presenter on TvOne. From this relevant research, it shows that research on 


\section{JOURNAL OF CRITICAL REVIEWS}

ISSN- 2394-5125

VOL 7, ISSUE 19, 2020

the structure of news rhetoric on the Kabar Siang and Breaking News programs on TvOne has never been done before. Therefore, this research is important in the hope that it can add to scientific references in the news field.

\section{RESEARCH METHODS}

The research method used is the content analysis method. The type of content analysis used is qualitative content analysis. Qualitatively, the object of content analysis in the form of all types of communication recorded on the Kabar Siang and Breaking News on TvOne obtained by recording using a cellphone, and transcribed into written text (Emzir, 2012). For this reason, data collection techniques use record techniques and note-taking techniques that originate from the Kabar Siang and Breaking News programs.

The reason the writer chose TvOne was because the television was the most dominant in presenting news format on a national scale. The author sees a difference in the presentation of news that is packaged on other televisions. This was made clear by TvOne's slogan, "It's Different". The Kabar Siang program used in this study is a live broadcast on December 17 and 182018 at 11:00 WIB until 13:00 WIB. Then on weekends on December 22, 2018 from 12.00 WIB until 13.00 WIB. Whereas the Breaking News used in this study were live broadcasts on December 29, 2018 from 11.54 West Indonesia Time to 12.14 West Indonesia Time, then on January 1, 2019 from 10.14 West Indonesia Time to 11.06 West Indonesia Time and on January 10, 2019 at 13.23 West Indonesia Time until 14.01 West Indonesia Time.

The data in this study were in the form of live news shows on Kabar Siang and Breaking News on TvOne. Data in general are in the form of news structure which includes, opening, content, and closing, while specifically in the content section covers the news structure namely lead, news body, and closing (news ending) and contains news elements $(5 \mathrm{~W}+1 \mathrm{H})$. The data source in this study is the Kabar Siang and Breaking News on TvOne broadcast live.

Data analysis procedures in this study used qualitative content analysis procedures with the development of inductive categories. The steps of developing the inductive category based on Mayring (2000) opinion are as follows: 1) establishing questions in research with the formulation of the problem namely how is the news structure on the Kabar Siang and Breaking News programs on TvOne which include, opening, content, and closing? 1) Determination of the definition of categories and the level of abstraction for inductive categories. Categories included in the news structure at the Kabar Siang and Breaking News events. 2) Step by step the formulation or formulation of data based on the definition of categories and the level of abstraction, sorting the old categories or formulating new categories. This category is made in the form of tabulating data. 3) Conduct revisions to the categories when they have reached $10-15 \%$ of the material as a form of formative checking or reliability by taking into account the problem formulation. 4) Make a final settlement of the entire text as a form of checking the validity or reliability of the sumative. and 5) Performing interpretation and final conclusions from the results of each category at the Kabar Siang and Breaking News on TvOne. Then, test the validity of the data using a way of discussing with experts, checking, and documenting all data on the Kabar Siang and Breaking News shows on TvOne in the form of video and news transcriptions.

\section{RESULTS AND DISCUSSION \\ Results}

\section{News Structure in the Kabar Siang Program}

The news structure of the Kabar Siang program begins with an opening remarks. This section was found at the beginning of the program delivered by the announcer. This indicates the event will begin. The opening speech delivered by the announcer at Kabar Siang has similarities and does not meet the easy listening formula because the sentence structure is more than 20 words.

The contents of the Kabar Siang event structure were found as many as 13 news topics that met the requirements, while those that did not meet the requirements were found as many as 29 news topics. Structure there are also found as many as 8 news topics that are said to qualify, while those that do not meet the requirements found as many as 23 news topics. Then, the news structure was also found as many as 5 news topics that were said to be eligible, while those that did not meet the requirements were found as many as 15 news topics.

The content section specifically has a structure consisting of leads, a news body, and a news ending. Each news topic has a news structure that contains varied news elements. Then, it meets the requirements if the news structure contains news elements that include what, who, when, where, why, and how. This $5 \mathrm{~W}+1 \mathrm{H}$ element should be described in the lead and news body section to meet the requirements, if it does not contain the $5 \mathrm{~W}+$ $1 \mathrm{H}$ element, then it does not meet the requirements.

The news structure of the Kabar Siang program ends with a closing marker and closing greetings. This section is found at the end of the program delivered by the announcer. This indicates that the event has finished. The closing sentence and closing greetings sent by the announcer at Kabar Siang have similarities and do not meet the easy listening formula because the sentence structure is more than 20 words. 


\section{JOURNAL OF CRITICAL REVIEWS}

ISSN- 2394-5125

VOL 7, ISSUE 19, 2020

The structure of the Kabar Siang program is arranged in an inverted pyramid pattern in which the composition of news items starts from the most interesting, interesting, to less interesting at the end of the event. Pulling or not a news based on the topicality and appeal and usefulness of the news.

\section{News Structure in Breaking News Program}

The structure of news in the Breaking News program generally has an opening (opening marker), content, and closing (closing marker and closing greeting). The opening section of the three news as research data has in common. This section is found at the beginning of the event delivered by the announcer indicating the event will begin. The sentence at the opening (opening marker) of the Breaking News program delivered by the announcer fulfills the easy listening formula because the sentence structure consists of 12 words that are more coherent, sound good, and easy to understand when the announcer reads as an opening greeting at the beginning of the event.

The contents of the news structure at Breaking News each consists of 1 news topic. The content section specifically has a structure consisting of leads, a news body, and a news ending and contains news elements. Then, meet the requirements if the news structure contains news elements that include what, who, when, where, why, and how. This $5 \mathrm{~W}+1 \mathrm{H}$ element should be described in the lead and news body section to meet the requirements, if it does not contain the $5 \mathrm{~W}+1 \mathrm{H}$ element then it does not meet the requirements. The contents of the Breaking News program structure on two news items are eligible, while in one other news categories are categorized as not eligible.

The closing part (closing markers and closing greetings) of the Breaking News program on the three news stories has similarities. This section is found at the end of the event delivered by the announcer indicating the event has finished. Sentences in the concluding section (closing markers and closing greetings) Breaking News delivered by broadcasters do not meet the easy listening formula because the sentence structure is more than 20 words.

The structure of the program on the Breaking News program does not indicate a television news rundown arrangement, either with inverted pyramid patterns, peak and valley patterns, or patterns of separation of news types. Breaking News event structure follows the pattern of news structure that refers to the inverted pyramid that has leads, a news body, and a news ending, and contains news elements.

\section{DISCUSSION}

The news structure of the Kabar Siang program on December 17, 2018, December 18, 2018, December 22 , 2018, and on the Breaking News program on December 29, 2018, January 1, 2019, January 10, 2019 on TvOne ie the structure of news programs is generally found to have an opening marker, contents, and cover (closing markers and closing greetings). In particular the news structure has leads, a news body and a news ending, and refers to the inverted pyramid. This is the same as the opinion of Morissan (2008), that television news manuscripts consist of three parts namely, intro or lead, narrative body or news body, and closing section. In addition, Barus (2010) explained that the most recommended news structure refers to the inverted pyramid structure. The structure of inverted pyramid writing is a form of writing that prioritizes information that is considered the most important that is used as the headline or opening section commonly referred to as leads. Next, followed by important information that is explained in more detail, this section is called the body of news. Then, at the end of the news, it is closed with a less important part.

\section{News Structure in the Kabar Siang Program}

The news structure of the Kabar Siang program generally has an opening marker, contents, and closing (closing marker and closing greeting). The opening marker at the Kabar Siang event of the three news items examined has in common. This section was found at the beginning of the event delivered by the announcer indicating the event would begin. The sentence structure read by the announcer as an ideal opening marker is no more than 20 words that refer to the easy listening formula. This is the same as Fang's opinion (in Baksin, 2016) which explains that in order for the sentence structure to meet the easy listening formula, each sentence should be made for no more than 20 words. In the use of the Indonesian language in the field of journalism, the economic provisions of words are applied which negate the words of waste, so the sentences that meet the easy listening formula will be arranged, that is, the composition of sentences that when spoken is pleasant to hear and easy to understand.

In particular the news structure of the Kabar Siang program has a structure consisting of leads, a news body, and a news ending. Then, it is said to meet the requirements if the news structure contains news elements which include what, who, when, where, why, and how. This $5 \mathrm{~W}+1 \mathrm{H}$ element should be described in the lead and news body section to meet the requirements, if it does not contain the $5 \mathrm{~W}+1 \mathrm{H}$ element then it does not meet the requirements. This is the same as the opinion of Badjuri (2010), that the television news structure consists of leads, body of news, and cover. Lead usually consists of 20-30 words and contains elements of what, who, where and when. While the body of television news that contains a more detailed explanation of the lead in. The news body contains more in-depth descriptions that contain elements of what, why, and how. 


\section{JOURNAL OF CRITICAL REVIEWS}

ISSN- 2394-5125

VOL 7, ISSUE 19, 2020

The closing part (closing markers and closing greetings) of the Kabar Siang program at the end of the program delivered by the announcer indicates that the program has finished. The sentence structure read by the announcer as an ideal closing greeting is no more than 20 words that refer to the easy listening formula. This is the same as Fang's opinion (in Baksin, 2016) which reveals that for the sentence structure to meet the easy listening formula, each sentence should be made for no more than 20 words. In the use of the Indonesian language in the field of journalism, the economic provisions of words are applied which negate the words of waste, so the sentences that meet the easy listening formula will be arranged, that is, the composition of sentences that when spoken is pleasant to hear and easy to understand.

The contents section found in the Kabar Siang news program data are 13 news topics that are said to meet the requirements. While those who did not meet the requirements were found as many as 29 news topics. The following is an example of news structure on topic 4 that meets the requirements of news structure.

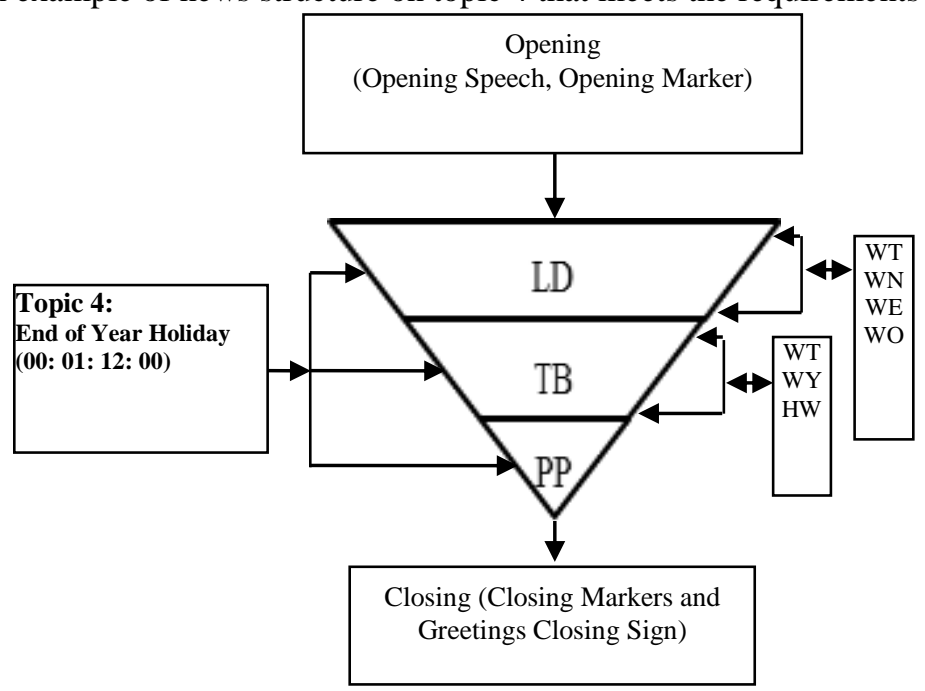

Fig. 1: News Structure in the Kabar Siang Program

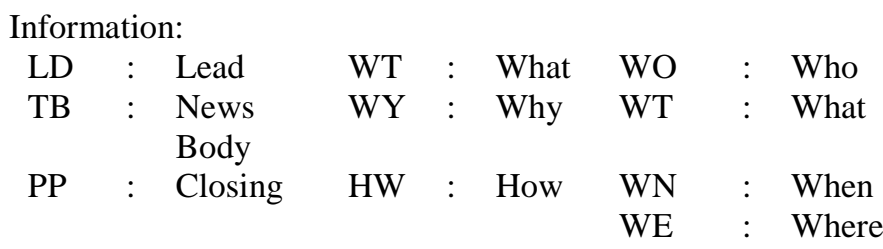

Then, based on data, the news structure of the Kabar Siang program on TvOne shows that editors compile news items starting from the most interesting, interesting, and less interesting at the end of the event. The composition of the news items found on the Kabar Siang program on TvOne shows that the editor compiles news programs using inverted pyramid patterns. This is the same as the opinion of Harahap (2018) that the pattern of the pyramid is reversed in the field of television reporting, the composition of news items starts from the most interesting news, interesting news, and less interesting news.

\section{News Structure in Breaking News Program}

The news structure of the Breaking News program is generally found to have an opening marker, a contents, and a closing (closing marker and closing greeting). The opening marker for the Breaking News program on the three news items studied has similarities. This section is found at the beginning of the event delivered by the announcer indicating the event will begin. The sentence structure read by the announcer as an ideal greeting is no more than 20 words that refer to the easy listening formula. This is the same as Fang's opinion (in Baksin, 2016) which reveals that for the sentence structure to meet the easy listening formula, each sentence should be made for no more than 20 words. In the use of the Indonesian language in the field of journalism, the economic provisions of words apply which negate the words of waste. Then, sentences will be arranged that meet the easy listening formula, which is a sentence that is pleasant to hear and easy to understand.

In particular the news structure of the Breaking News program has a structure that consists of leads, a news body, and a news ending. Then, it is said to meet the requirements if the news structure contains news elements which include what, who, when, where, why, and how. These $5 \mathrm{~W}+1 \mathrm{H}$ elements should be described in the lead and news body sections to qualify. If it does not contain the $5 \mathrm{~W}+1 \mathrm{H}$ element, it does not qualify. This is the same as the opinion of Badjuri (2010) that the television news structure consists of leads, body of news, and 


\section{JOURNAL OF CRITICAL REVIEWS}

ISSN- 2394-5125

VOL 7, ISSUE 19, 2020

cover. Lead usually consists of 20-30 words and contains elements of what, who, where and when. While the body of television news that contains a more detailed explanation of the lead in. The news body contains more in-depth descriptions that contain elements of what, why, and how.

The structure of news in the Breaking News program which is categorized as eligible can be shown in one of the following news stories about the 7.1 SR Quake.

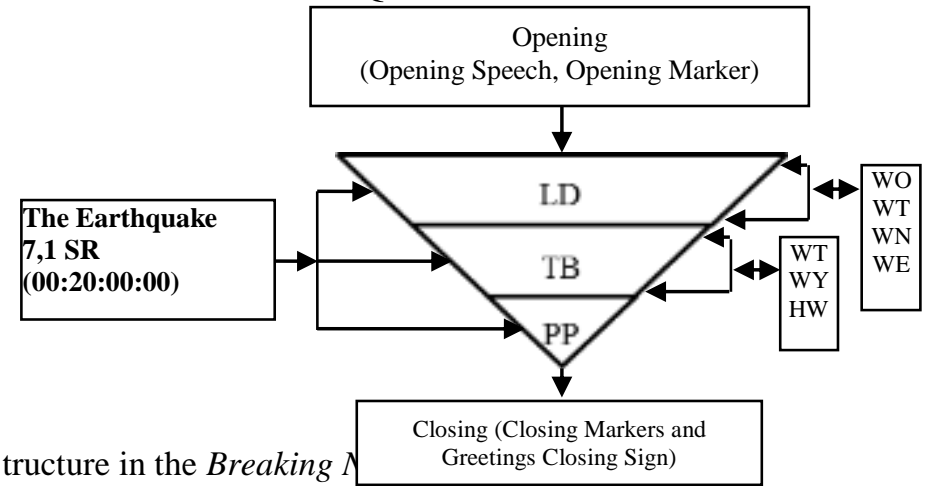

Fig. 2: News Structure in the Breaking $\quad \begin{array}{r}\text { Closing (Closing Markers and } \\ \text { Greetings Closing Sign) }\end{array}$

The structure of news in the Breaking News program in the picture above there is only 1 news topic with a duration of 20 minutes without commercial breaks. However, the structure of the Breaking News program follows the pattern of news structure that refers to the inverted pyramid that has leads, a body of news, and a closing section and contains news elements.

Based on the data, the pattern of news structure in the Breaking News program on TvOne does not show a television news rundown arrangement, either with inverted pyramid patterns, peak and valley patterns, or patterns of separation of news types. This is different from the opinion of Harahap (2018) who revealed that the television news rundown is the arrangement of news items that will be aired until the end of the event. A systematic rundown has a big influence on the attractiveness of the audience so they can watch the series of events from beginning to end.

Based on the results of research conducted by Maulana \& Fatmawati (2018) with the title "Analysis of Indonesia Morning Show News Program Production in News and Entertainment Television" with the aim to find out how the production, production process, and production analysis of Indonesia Morning Show news program in NET. The TV. The results of his research found that in the implementation of the Indonesia Morning Show news program on NET. TV goes through three main stages namely pre-production, production, and postproduction. Then, in the packaging of the news, the Indonesia Morning Show changed the format in writing news scripts to S-P-O-K from those that normally use $5 \mathrm{~W}+1 \mathrm{H}$ elements. While the results of this study found that the news structure at the Kabar Siang and Breaking News program on TvOne was preceded by an opening remark delivered by the announcer at the beginning of the event. At Kabar Siang program this section does not meet the easy listening formula, while the Breaking News program meets the easy listening formula. The content section of the Kabar Siang program consists of topics 1 to 42 from 8 segments, while Breaking News only has 1 topic from 1 segment. Each topic has a varied news structure consisting of leads, body of news, and news ending and contains elements of $5 \mathrm{~W}+1 \mathrm{H}$. The Kabar Siang and Breaking News program ended with a closing marker and closing greeting delivered by the announcer. This section is equally not meet the easy listening formula. The news structure in Kabar Siang is arranged in an inverted pyramid pattern in which the composition of news items starts from the most interesting, interesting, to less interesting based on the actuality and attractiveness of the news. While the news structure of the Breaking News program only follows the pattern of news structures namely leads, body of news, and news ending.

\section{CONCLUSION}

From the results of this study it can be concluded that the news structure of the Kabar Siang and Breaking News program on TvOne begins with an opening marker, continues with the content section, and ends with a closing (closing marker and closing greeting). From the results of research on the Kabar Siang and Breaking News programs on TvOne have the following differences and similarities:

\section{News Structure in the Kabar Siang Program}

The structure of news in the Kabar Siang program begins with an opening remark. This section is found at the beginning of the event delivered by the broadcaster, this indicates the event will begin. The opening greeting sentences delivered by the announcer at the Kabar Siang program have similarities and do not meet the easy listening formula because the sentence structure is more than 20 words.

The contents of the Kabar Siang program structure have 13 news topics that are said to be eligible, while 29 non-qualified news topics are found. There is also a news structure that has 8 news topics that are said to be eligible, while 23 non-qualified news topics are found. Then, there is also a news structure that has 5 news topics that are said to be eligible, while 15 non-qualified news topics are found. 


\title{
JOURNAL OF CRITICAL REVIEWS
}

\author{
ISSN- 2394-5125 \\ VOL 7, ISSUE 19, 2020
}

The content section specifically has a structure consisting of leads, a news body, and a news ending. Each news topic has a news structure that contains varied news elements. Then, it is said to meet the requirements if the news structure contains news elements which include what, who, when, where, why, and how. This $5 \mathrm{~W}+1 \mathrm{H}$ element should be described in the lead and news body section to meet the requirements, if it does not contain the $5 \mathrm{~W}+1 \mathrm{H}$ element then it does not meet the requirements.

The news structure of the Kabar Siang program ends with a closing marker and closing greetings. This section is found at the end of the program delivered by the announcer. This indicates that the event has finished. The closing sentence and closing greetings sent by the announcer at Kabar Siang have similarities and do not meet the easy listening formula because the sentence structure is more than 20 words.

The news structure of the Kabar Siang program is arranged in an inverted pyramid pattern in which the composition of news items starts from the most interesting, interesting, to less interesting at the end of the event. Pulling or not a news based on the topicality and appeal and usefulness of the news.

\section{News Structure in Breaking News Program}

The structure of news in the Breaking News program generally has an opening (opening marker), content, and closing (closing marker and closing greeting). The opening section (opening markers) on some of the news on Breaking News have in common. This section is found at the beginning of the event delivered by the announcer indicating the event will begin. The sentence at the opening (opening marker) of the Breaking News program delivered by the announcer fulfills the easy listening formula because the sentence structure consists of 12 more coherent words, sounds good and is easy to understand when the announcer reads as an opening greeting at the beginning of the event.

The contents section of the news structure in the Breaking News program each consists of 1 news topic. The content section specifically has a structure consisting of leads, a news body, and a news ending and contains news elements. Then, it is said to meet the requirements, if the news structure contains news elements that include what, who, when, where, why, and how. These $5 \mathrm{~W}+1 \mathrm{H}$ elements should be described in the lead and news body sections to qualify. If it does not contain the $5 \mathrm{~W}+1 \mathrm{H}$ element, it does not qualify. The contents of the Breaking News program structure category are categorized as eligible, and some are categorized as not qualified.

The concluding section (closing markers and closing greetings) of the Breaking News program on the three news items studied has similarities. This section is found at the end of the event delivered by the announcer indicating the event has finished. Sentences in the concluding section (closing markers and closing greetings) Breaking News program delivered by broadcasters do not meet the easy listening formula because the sentence structure is more than 20 words.

The structure of news on the Breaking News program does not indicate the existence of a television news rundown arrangement, both with inverted pyramid patterns, peak and valley patterns, and patterns of separation of news types. The news structure of the Breaking News program follows a news structure pattern that refers to an inverted pyramid that has leads, a news body, and a news ending and contains news elements.

From the conclusions about the structure of news rhetoric on the Kabar Siang and Breaking News program on TvOne, it shows that there are still many news structures that do not meet the requirements, said to be eligible if the news structure contains news elements that include what, who, when, where, why, and how. These $5 \mathrm{~W}+1 \mathrm{H}$ elements should be described in the lead and news body sections to qualify. If it does not contain the $5 \mathrm{~W}+1 \mathrm{H}$ element, it does not qualify. Therefore, recommendations are needed to various parties as follows: 1) TvOne, in order to improve the quality of news programs, it is suggested to keep paying attention to the structure of the news before it airs. This is to maintain professionalism in broadcasting news programs and as a role model in broadcasting news on television. 2) Journalism, in order to maintain professionalism in the field of journalism as a writer and broad disseminator of information to the public, it is advisable to keep paying attention to writing news according to the rules of the news structure. Then, 3) Indonesian language teacher, findings about the structure of news rhetoric in the Kabar Siang and Breaking News program on TvOne can be used as one of the teaching materials when teaching material about news.

\section{AKNOWLEDGMENT}

The authors thank to Rector of Universitas Bengkulu, STKIP PGRI Lubuklinggau, Universitas Muhammadiyah Bengkulu, and Universitas Majalengka, all lectures and employees, as well as all those who have helped a lot in writing this paper.

\section{REFERENCES}

[1] Anwari, A. (2013). Media Massa dalam Bingkai Kekuasaan (Analisis Wacana Berita Munas Golkar di Metrotv dan tvOne). KANAL: Jurnal Ilmu Komunikasi, 1(2), doi:10.21070/kanal.v1i2.335

[2] Badjuri, A. (2010). Jurnalistik Televisi. Yogyakarta: Graha Ilmu.

[3] Baksin, A. (2016). Jurnalistik Televisi Teori dan Praktik. Bandung: Simbiosa Rekatama Media. 


\section{JOURNAL OF CRITICAL REVIEWS}

[4] Barus, S. W. (2010). Jurnalistik Petunjuk Teknis Menulis Berita. Jakarta: Erlangga.

[5] Chaer, A. (2010). Bahasa Jurnalistik. Jakarta: Rineka Cipta.

[6] Dewi, F.U. (2016). Public Speaking Kunci Sukses Bicara di Depan Publik Teori \& Praktik. Yogyakarta: Pustaka Pelajar.

[7] Emzir. (2012). Metodologi Penelitian Kualitatif: Analisis Data. Jakarta: PT Raja Grafindo.

[8] Gusdian, R. I. (2016). Penggunaan Kata Sapaan oleh Pembawa Acara Apa Kabar Indonesia (AKI) di TV ONE. Kembara, 2(2), http://ejournal.umm.ac.id/index.php/kembara/article/view/4006

[9] Harahap, A.S. (2018). Manajemen Pemberitaan dan Jurnalistik TV. Jakarta: Indeks.

[10] Karto, Suhartono, Susetyo, Noermanzah, Maisarah, I. (2019). The Differences Ability In Writing Descriptive Texts By Using Chain Writing And Conventional Methods. International Journal of Scientific \& Technology Research, 8(10), www.ijstr.org/paper-references.php?ref=IJSTR-1019-24157

[11] Kusmiarti, R., Yuniati, I., Noermanzah. (2020). Improving Student Communication Skills in Learning Indonesian Language through Collaborative Learning. International Journal of Scientific and Technology Research, 9 (1), http://www.ijstr.org/paper-references.php?ref=IJSTR-0120-27801

[12] Kusumaningrat, H. \& Kusumaningrat, P. (2014). Jurnalistik Teori \& Praktik. Bandung: PT Remaja Rosdakarya.

[13] Maulana, K.A. \& Fatmawati, F. (2018). Analisis Produksi Program Berita Indonesia Morning Show di News and Entertainment Television. Profetik : Jurnal Komunikasi, 11(2), http://ejournal.uinsuka.ac.id/isoshum/profetik/article/view/1423/1285

[14] Mayring, P. (2000). Qualitative Content Analysis. Forum Qualitative Sozialforschung (FQS), 1(2), http://www.qualitative-research.net/index.php/fqs/article/view/1089/2386

[15] Ministry of Education and Culture. (2017). Model Silabus Mata Pelajaran Sekolah Menengah Pertama/Madrasah Tsasnawiyah (SMP/MTs) Mata Pelajaran Bahasa Indonesia. Jakarta: Kementerian Pendidikan dan Kebudayaan.

[16] Morissan. (2008). Jurnalistik Televisi Mutakhir. Jakarta: Kencana Prenada Media Group.

[17] Noermanzah, Emzir, \& Lustyantie, N. (2018). President Joko Widodo's Rhetorical Technique of Arguing in the Presidential Speeches of the Reform Era. International Journal of Applied Linguistics and English Literature, 7(5), 119. doi:10.7575/aiac.ijalel.v.7n.5p.117

[18] Noermanzah, Wardhana, D. E. C., Friantary, H., Arsyad, S. (2019). Joko Widodo's Rhetorical Structure In The Presidential Speeches For Addressing Educational Problems. International Journal of Scientific \& Technology Research, 8(10), http://www.ijstr.org/paper-references.php?ref=IJSTR-1019-22878

[19] Saragih, M. Y. (2019). Media Massa dan Jurnalisme: Kajian Pemaknaan antara Media Massa Cetak dan Jurnalistik. Jurnal Pemberdayaan Masyarakat, 6(1), doi:10.37064/jpm.v6i1.4988

[20] Seto, I \& Morissan, M. (2013). Menilai Objektivitas Isi Berita Media Televisi Swasta Nasional. Jurnal Visi Komunikasi, 12(1), http://publikasi.mercubuana.ac.id/index.php/viskom/article/view/380

[21] Surip, Mhd. (2016). Analisis Isi Berita di Stasiun Televisi “TVRI, SCTV dan Metro TV”. Bahas, 27 (1).

[22] Syafryadin, Wardhana, D.E.C., Apriani, E., Noermanzah. (2020). Maxim Variation, Conventional and Particularized Implicature on Students' Conversation. International Journal of Scientific and Technology Research, 9 (2). http://www.ijstr.org/paper-references.php?ref=IJSTR-0120-30135

[23] TvOne. (2018). Program Unggulan TvOne. Accessed December 1, 2019, from http://www.tvonenews.tv/jadwal

[24] Verawati, E., Wibisono, B. \& Rochiyati, A. E. (2014). Ciri-Ciri Bahasa Running Text pada Kabar Pagi di Channel TVOne. Publika Budaya, 3(2).

[25] VIVA. (2018). The Leading Media Convergent Company. PT Visi Media Asia Tbk: Accessed December 5, 2019, From https://id.vivagroup.co.id/tentang-kami/penghargaan-dan-sertifikasi/ 